\title{
LETTING FEAR GO: AN INTEVIEW WITH PRODUCER PARAMITA BANERJEE
}

\author{
Mónica Fernández Jiménez \\ Universidad de Valladolid
}

I first met Paramita Banerjee in the winter of 2019 when I was invited to the screening of Bridge (2016), a film she had produced. Little did I know that this film would touch me in so many unexpected ways, completely changing my perception of what caring and being cared for means. That beautiful Salamanca evening ended with the chiming of the cathedral's bells at midnight, and I went back to my hotel to sleep. The next morning, I planned to do some work at the university library whilst waiting for my train, but before I arrived, I ran into Paramita and some colleagues. I cannot recall the progression of events leading to this, but we found ourselves scrolling through the historical archives of the University of Salamanca, astounded by the many medical treatises of the sixteenth century that the institution harbors, as well as some of the first world maps to ever have been drawn.

To me, a student newly embarking on her $\mathrm{PhD}$, having moved cities several times to pursue my academic career, each time having to start anew without any acquaintances or old friends to rely on, Paramita's warmth meant so much at the moment. The unconditional hospitality with which she approaches anyone new that she meets filled me with hope. Now I know that Paramita is a Rabindra Sangeet singer and film producer based in London and has recently released a new album titled Kharobayu. Without her dedication and faith in independent cinema, Bridge would not have been possible. Paramita has always been extremely kind to share her knowledge with us and today she will be telling us a bit more about her own experiences in the world of arts.

Mónica Fernández Jiménez (MFJ): Paramita, thank you very much for allowing me to carry out this interview, it is such a pleasure and I am so impressed by your work on film production. We often hear accounts of what it is like to direct a film or act in one, but producers' testimonies are not as commonly widespread. Could you tell us a bit more about your job and what it consists of?

Paramita Banerjee (PB): I am going to respond with an analogy someone once said to me: a producer is someone who has to organise a party. He or she will book the venue, put the guest list together, prepare the venue, arrange the food, make everything spick and span, get the tables just right and then when everything is finished, stand and watch the party happen -making

DOI: https://doi.org/10.25145/j.recaesin.2021.83.17

Revista Canaria de Estudios Ingleses, 83; November 2021, pp. 223-229; ISSN: e-2530-8335 
sure the party is a success! You can't eat, drink or do anything while you are at the party. You just have to sit and watch people eat and drink and be happy and hope this party is going to go well. I think, in film terms, this is what a producer does.

When you attempt to define a producer there are many differences to consider. Hollywood has this kind of producer like George Lucas. I am sure he doesn't make tea, but I make tea when I am on a set. There is this macrocosmic producer and there is a microcosmic independent producer. However, if you look at it from the theoretical point of view, both will find a script or a novel that they like and decide to make a film out of it. They will next find a scriptwriter and then they will buy the rights or get a company to do so. This is how a script is born. Then they are going to obtain some money and once the money comes in -simultaneously, I would say- they will find the director best suited for the script. Then they will make sure there is a casting director. Basically, the point of inception is the producer. The producer starts the journey and there is usually a collaboration between the producer and the director. This is the initial marriage. There are many marriages in a film: there is a marriage between the director and the cinematographer, between the cinematographer and the editor, between the editor and the colorist... there are various relationships and that is why filmmaking is so challenging and exhausting. There are often so many strong personalities, all having their own creative ideas, so part of the job of a producer is to find people who see the film differently. Similarly, and differently. They see the big picture but then they add to it. Ultimately the film is the vision of the director, this is why the director is so important. A producer sees it from the sales point of view... so he or she will find the right director who has the right artistic vision for this film. Although there is a huge difference between big production producers and small production producers, they all basically carry the inception of the idea. It can be a sentence or an original script. This is the exciting bit for the producer because it all starts from a sentence, or a conversation, or from reading a book, and then eventually the film is in theatres or on Netflix or Amazon these days.

MFJ: So we can agree that this is an extremely important job! Without a producer there would certainly be no film. He or she is the backbone or the building blocks of the film. Considering all this, do you think production work is under-appreciated?

PB: If you watch a film with Tom Cruise or Matt Damon in it, obviously the producer is not going to get the attention, but I guess those producers have to be at peace with that, and if the face of the film sells, the film gets sold. In a way a producer has to be quite detached from their own ego and their own claim to fame or popularity because what he or she is doing is bringing people together, people who will make this film happen and whose faces or names are going to sell. I just wonder whether popularity or name recognition is the ultimate sign of success, because of course there are other things that matter. Some people are very private and may not want the attention. You 
are right though, producers are under-appreciated, I completely acknowledge that -there is no question- but the challenge of a producer is to live with that because a producer is not a star. He or she does not have the body of Matt Damon but he or she knows that James Bond's body is going to sell James Bond and the franchise is going to make money for the producer. This is the deal. From my point of view, you have to be happy and contented with it. If you crave for attention, I think this is not the job for you.

MFJ: This is very interesting. It means that it is part of the job to deal with the dynamics of appreciation and recognition and at the same time make sure that the film exists.

PB: Yes, the producer has to be the jellying element [sic] who says "the film is the most important thing." So "let's think of the film."

MFJ: So in this sense, would you say there have been any personal challenges related to your system of values that you have had to face in the production of films?

PB: Not really in terms of values because I came into this job by chance. Amit [the director of Bridge] and I love cinema, we watch a film a day. Amit had been writing a lot of theatre and doing very well and then we met Mr. Chatterjee, the protagonist of our film. To cut a long story short, that is when we started to think that we could make a film. There was no question that we would make it together because this was completely a work of passion. This was not planned, it was accidental; it was never my intention to become a film producer, but I love cinema. The challenge was that Amit and I have a personal relationship so it was difficult to have a boundary. There were lots of screaming on the sets but what we were doing was like raising a child. When you raise a child, you keep the child at the forefront. Egos, even if they arise, must be set aside.

I'll tell you a story. Everybody hated the first cut of the film, and we hated it too, which was relieving. But when we hated it, that's when we forgot that everybody hated it. A film goes through various editing processes and then the music and the sound are slowly introduced and voilà! One day you feel that this is what you were looking for. I am not saying that we have created a masterpiece but it is something that we love. If I have to sell a soap, I have to love it. If I do not use it, nobody else will. I wanted to love Bridge first before I expected anybody else to love it. Just before the final version, every week we watched the film once, just to see what could be done, and one day I realised that during one particular sequence I would always get up to make a cup of tea. I thought, this can't be a coincidence. I told Amit that he should drop these few scenes and see how the film worked. There were obviously fireworks in the house, considering we had spent so much time filming these scenes. Any work of art eventually amounts to editing it, to see what can be thrown away, and it can sometimes feel as if the best bit is being left out. Eventually Amit agreed. To my delight, once the scene was cut the film was flowing better, and Amit said: "yes, you are right." This is the producer's job, to have that detachment from the film, because as a 
director or as an actor you are too close to it. I think we have to have that tough love and even if we spent half a day shooting this, we can admit it is not working.

MFJ: This film is beautiful, and I could see that its inception was a very personal process. What are your thoughts on the reception of Bridge as an independent film of intimist content? Are there any significant differences in the reception depending on the country or the context where it was presented?

PB: Thankfully it was universal. We have only screened it in film festivals so far. We have not been able to release the film. We were supposed to release it theatrically in India last year, but we could not because of Covid. Wherever we went there were tearful eyes in the end. There were people who held our hands and said "thank you for making this film." It is very humbling. I think it is universal; cinema is universal language. We have created a story which happens everywhere and is relevant everywhere. I have yet to meet anyone who has disliked the film, although there may be. We need to have that detachment because the fact that I like something does not mean that everyone else likes it. I do not like violent films, for example. I am not obsessed with the fact that everybody has to love it, but so far we have had brilliant responses from people. Even if we do not make money out of this film, what Amit and I had in common is that we did not want to die without making a film. I think that conviction is still true.

MFJ: Bridge is filmed in a very special location, Bally. As per the film's website, which I am quoting, this is "a suburban town just outside Kolkata where the 82-year-old Bridge crosses the majestic Ganges." Film locations bear great significance for the plot and the message, which is very striking in the case of Bridge. In the same website it says that "[b]ridges all over the world have a history of visitations of men and women, victims of misfortune, with the resolve to end their lives." They are also places of encounter, uniting different worlds in some occasions. This is all very present when one watches the film. There must though be other stories, lived by the producers and those working on set whilst interacting with local people and the local environment, which the audience does not get to experience. Can you tell us anything remarkable about producing a film in Bally?

PB: I am glad you mention the location because this was the house where I grew up, it was not a hired place. And since this is an independent film, we had to cut costs wherever it was possible. Having a free location meant that we could work extended hours. Because it is a big space, we could also convert things, we could convert one part of the room and then make another part of the room into another setting. This is the rational side. It is also a place which is close to my heart because it is my ancestral home, it is where my grandparents lived, where we lived as children. This is a very emotional space for us and we go back every year. Everybody knows us in the town as well, so there were people stopping on the street to look and we used to ask them if we could get a shot from them. One day I remember there was a very elderly woman, in her 90 s or even a hundred, who was walking with a 
stick completely bent. She was gorgeous, independent and fine, so we asked her if we could take a shot of her walking with our camera and she said "you know darling, I have to go to the bank, I haven't got the time." These are the memories, we employed the local people to work for the set, we employed local caterers to do the food, everybody who knew us as a family. And that bridge is amazing because it is not used very much, but we had to shoot at 3 in the morning, so the location is extremely special. There is the river as well, which is part of the Ganges. And from the very technical point of view, we did not have to pay anything. It was like a party.

MFJ: Apart from being a producer, you are also a music content creator and performer. It is so nice to hear about the more emotional aspects of being a producer and so continuing with this theme, what would you say are the main differences between your production job and your musical work?

PB: Essentially, I am a very highly strung emotional person. I cry at good endings, happy endings. I also cry at sad endings, obviously. I watch Love Actually and I weep. I am deeply emotional generally; however, I have a technical side. I worked in a bank and I am a list maniac. If you take a look at my diary, it is full of lists of things to do. That is my control freak side. I like things to be in control, which helps for being a producer. It might turn me out, it might affect my psyche to some extent, but I enjoy it. I love being in control of everything that is happening around me. But also, I never have considered myself to be a solo artist.

On stage one is vulnerable so one is dependent on other musicians to be carried through. While you are singing there are other people around you who are taking you through this journey. I would hate to say I am a solo artist and producing is also a team work. I love team work. I derive inspiration from people. Frankly, I love collaborating and working with people, and that builds relationships. That is where I find a similarity. Furthermore, I do not personally think you can demarcate art. You have a relationship with all art forms through a single mind which is going to affect your experience of a piece of art. Your experience will also be completely different from that of other people. A farmer from India, if he or she watches Van Gogh, is going to react completely differently to how an art critic would. Our psyche determines how we react in similar ways to all art forms.

When I perform, however, I try to be objective. I think that is the only way that I can grow. That is the big similarity with film making. I do not write my songs, I sing a particular genre which comes from Tagore, the Nobel laureate from India. I tell myself that I am the audience of my songs and that I need to see if I can do better. I obviously have limitations, but am I doing the best that I can? The best interpretation of the song? Similarly with Bridge, when I was drinking tea, I knew there was something going on with that clip. That is the objectivity I try to have. The problem with emotional people, that I certainly am, is that they get easily carried away. But if I believe I am the best singer on the planet I am limiting myself. I am limiting my art form. 
MFJ: You have just said that you approach both of your jobs through your particular mindset regarding art. Do you think there is anything to be gained from the fact that you are combining them as well? Would it be any different if you did only one of the two?

PB: A hundred percent. Music obviously has a huge part on it because of the sound. I am going to give you an example of how it helped me in this particular context. I think being a butcher is going to help you in filmmaking because you will know how to cut without passion. Filmmaking is so diverse that you can bring on to plate any talent that you have. Music is something that gives sensitivity about rhythm. Music is not always about tone; it is about rhythm. Because I am a musician it has created my gut. The fact that I realised that there was a moment when I went to make tea because the rhythm of the film was slowing has to do with music.

Music is flow, you know what needs to come after. It is quite mathematical in a way. There was one scene where we were struggling to add the music, nothing worked. And then I remembered one lullaby that my father could sing well despite being completely tone deaf, very bad at music. And it worked well, and we could use it. Any sensitivity, any talent can be brought. It is about being exposed to art and exploring one's vulnerable side. I think everybody is an artist but sometimes we have to resist it because art moves. If art moves me, it can also bring me down. I can handle it. I want it to touch me. I want it to make me cry. I saw the Pietà in the Vatican and I started weeping uncontrollably and I was thinking: "is it my hormones, what is it?" But then I thought: "if I am exposing myself to that embarrassment, let me do it, let me enjoy it."

MFJ: Of course! Go ahead! Very much related to this, much of the content of Bridge is about the transformative power of human contact. What do you think you can achieve with your music in terms of transforming other people's realities?

PB: I think it is more about transforming myself. What I can do is having an immersive experience. I have sung in places where nobody spoke my language so I decided to have an immersive experience. I am immersed in my song, in my music, and if that touches another human being, I am grateful for that. I do not think I can claim that it is going to transform. I think Bridge is exactly the same thing. Whether it is going to transform someone, or touch someone, or make someone cry is not in our control. We use our art form to present something and of course there is a scientific mind presenting it. When you do your music, you know your rhythm, you cannot get carried away. When you do your film you need to edit it, you need to have your left brain working as well. When people say art is just your right brain, just the creativity, I disagree. It is a combination of both. Even in a painting there is structure, there is rhythm, there are blocks through which the artist thinks. There is the combination of the left brain and the right brain, otherwise I would go off on a tangent. All I can say is that I do what I can. I can train as well, I sing with a muscle, my vocal cords. If I go to the gym to work 
out, I have to practice this muscle to make sure it works and I can take it wherever I want. I think it is a combination of both aspects.

MFJ: When I first watched the film I remember having a debate about some of its meanings and I specifically remember that some of us came up with interpretations which you and Amit did not share or had not thought of. It seems like the film itself went through a process of transformation in its contact with the viewers. How does this transformation work in the case of music? Have you been transformed by your listeners?

PB: I am sure I have, but unconsciously, because I have performed in front of eight to eight thousand people. Zero when I am practicing because I think I sing the best when I am on my own, when I am completely uninhibited. As I was growing up, I was extremely nervous about performing because I had an expectation on myself, I was worried I would go wrong. But if I have one achievement in my life, it is that I have become free. When I go on stage, I think that if I go wrong, it is completely fine, at least I am enjoying it. When the audience has responded when I am free, I think that has made me freer. I think I have been liberated by the experience I have had when I am performing on stage with an audience around me. I usually shut my eyes and I sing; I do not want to see anyone. I know they are there but I do not want to see them because I want to make it as immersive as possible. I think they have transformed me in a way that I could just be free and all that fear is gone.

MFJ: That is a beautiful answer. I think that is what Bridge is about, the letting go of fear, achieved through human interaction and contact. Thank you very much Paramita. 
